\title{
Corrigendum: A forward chemical genetic screen reveals an inhibitor of the Mre11-Rad50-Nbs1 complex
}

Aude Dupré, Louise Boyer-Chatenet, Rose M Sattler, Ami P Modi, Ji-Hoon Lee, Matthew L Nicolette, Levy Kopelovich, Maria Jasin, Richard Baer, Tanya T Paull \& Jean Gautier

Nat. Chem. Biol. 4, 119-125 (2008); published online 6 January 2008; corrected after print 13 February 2009

In the version of this article initially published, the reported chemical structure and systematic name for mirin (compound 1), identified from a high-throughput screen, were incorrectly assigned in the commercial library. Investigations by Garner, Pletnev and Eastman (Correspondence: Nat. Chem. Biol. 5, 129-130, 2009), which have been confirmed by us (Response: Nat. Chem. Biol. 5, 130, 2009), have identified the correct structure of mirin (see illustration below). The systematic name and chemical structure for mirin have been corrected in the HTML and PDF versions of the article, and in the graphical abstract and the PubChem database.

Original published structure and systematic name for mirin<smiles>O=c1cc(-c2ccc(O)cc2)[nH]c(=S)[nH]1</smiles>

6-(4-Hydroxyphenyl)-2-thioxo-2,3-dihydro-4(1H)-pyrimidinone
Corrected structure and systematic name for mirin<smiles>N=C1NC(=O)/C(=C/c2ccc(O)cc2)S1</smiles>

Z-5-(4-Hydroxybenzylidene)-2-imino-1,3-thiazolidin-4-one

\section{Corrigendum: Small molecule versus DNA repair nanomachine}

\section{James T Stivers}

Nat. Chem. Biol. 4, 86-88 (2008); published online 17 January 2008; corrected after print 13 February 2009

In the version of this article initially published, the chemical structure of mirin in Figure $1 \mathrm{~b}$ was incorrect. The error has been corrected in the HTML and PDF versions of the article.

\section{Corrigendum: In this issue}

Mirella Bucci

Nat. Chem. Biol. 4, v (2008); published online 17 January 2008; corrected after print 13 February 2009; doi:10.1038/nchembio0208-v

In the initially published version, the chemical structure of mirin displayed in the section entitled "Small molecules in ATM transactions" was incorrect. The corrected structure of mirin is now provided in the HTML and PDF versions of this 'In this issue' section. 